\title{
Career Guidance for Self-Knowledge and Occupation Knowledge of Cerebral Palsy Students in Special Senior High School
}

\author{
E.P. Sartinah \\ Universitas Negeri Surabaya \\ Surabaya, Indonesia
}

\begin{abstract}
This research aims to examine the effectiveness of career guidance service product for self-knowledge and occupation knowledge through the advisability and accuracy test. This research use Borg \& Gall research and development procedure, with the used of two-cycle steps, including (1) main field test or small scale 2 ) revise the final product. These test procedures have been done through the analysis of descriptive quantitative. In result, based on the effectiveness test, this product is effective to optimize the change of knowledge related to interest knowledge, ability knowledge, personality knowledge, value and behavior knowledge, future goals knowledge, and individual mindset toward occupation and connecting between occupations and self-potential. While the t-test result of pre-test and pos-test analysis which is related to self-knowledge shows less significant. It happened because of the students got a psychological problems such as the difficulty to express their minds, wills or wishes.
\end{abstract}

Keywords- Career guidance, self-knowledge, occupation knowledge

\section{INTRODUCTION}

Cerebral palsy students have limitation, permanent abnormalities or impairments that defects the locomotors (bones, joints, muscles) so that they require special education services, because they still have a potential to be developed $[10,11,12]$. This causes cerebral palsy students have low selfefficacy, especially aggravated with community views that underestimate cerebral palsy student's ability. Being a citizen who has a low self-efficacy lead cerebral palsy students have a lack of motivation to develop their potential for future career. An attempt to make students who have a deficiency (children with special needs) to become independent individuals, the government and educational institutions design an educational curriculum for students with special needs more emphasis on the skills aspects. The attempts to make the cerebral palsy students to be independent is by applying the skills aspect more than the cognitive aspect, leading to a career of cerebral palsy graduates only able to work in sectors, which are mechanical and routine. They are less able to explore their potential. Super (1980) states that the self-knowledge is a courageness to know, to recognize, to understand, to realize, and to accept their condition as it is, and it is an early stage that must be possessed by individuals in order to develop career in accordance with their potentials [8]. This fact often does not happen to cerebral palsy students in self-knowledge. The results of observation that has been done in special senior high schools in 2015, the counselors found difficulty in providing an effective career guidance services for cerebral palsy students.

The career guidance service for self-knowledge and occupation knowledge for cerebral palsy students is designed as a step towards to improve their success in their careers, as Gibson \& Mitchell (2008) argues, that often cerebral-palsy students generally experience confusion, hesitancy, and difficulty preparing in choosing and entering the world of work [2]. One approach which is relevant to an understanding of self and occupation is the theory of Cognitive Information Processing (CIP) explained that there are three domains which are involved in career choices and problem solving, namely: (1) knowledge domain, (2) decision making skills domain, and (3) excecutive domain processing [4, 6, 8, 13]. Self-knowledge and occupation-knowledge contained in the knowledge domain. The strength of domain knowledge or understanding in CIP theory is that someone in the career planning begins by giving knowledge or understanding. Providing knowledge or understanding to the cerebral palsy students is intended for students from the beginning, so that they have a provision to prepare for career in the future. In relation to the career preparation of special senior high school cerebral palsy students, the product has been produced are $: 1$ ) guidance book for special senior high school cerebral palsy student's counselor and teacher, 2) cerebral palsy student manual, and 3) career guidance material books for selfknowledge and occupation knowledge.

So, based on the background description above, this study aims to examine the effectiveness of career guidance service product for self-knowledge and occupation knowledge through the advisability and accuracy test by using Borg \& Gall research and development procedure. As the result, the product is effective to optimize the change of knowledge 
related to interest knowledge, ability knowledge, personality knowledge, value and behavior knowledge, future goals knowledge, and individual mindset toward occupation and connecting between occupations and self-potential.

\section{METHOD}

The type of research used in the effectiveness of career counseling services products for self-knowledge and occupation knowledge on special senior high school cerebral palsy students is by adapting the development model of Gall, Joyce \& Borg (2007) [1]. In the implementation of product testing, test product trials are conducted to obtain data in the form of suggestions, responses, and criticism from experts and potential users who can be used as a basis for improving the resulting product development. This section includes: test design, test data type subjects, and data analysis techniques.

Data collection instruments used in this research is evaluation questionnaire [14, 15]. Questionnaires were developed to gather expert opinions about the acceptability of guidance counseling services on self-knowledge and occupation knowledge of special senior high school cerebral palsy students. Content experts and design experts asked to rate the acceptability of the package seen from three aspects:

- Usefulness

Refers to the acquisition of the product can benefit both for counselors and cerebral palsy students.

- Appropriateness

To find out how much the practicality and effectiveness of the product.

- Accuracy

Refers to how these packages can meet the needs of students palsy in career guidance for self-knowledge and occupation knowledge.

In analyzing the data, quantitative data were analyzed quantitatively. Quantitative data was obtained from expert test and user test. The criteria used are based on the judgments given by experts and potential users by spreading the questionnaires. Data obtained from expert opinion and potential users are classified into 4 response categories (values 1, 2, 3, and 4) and then converted in percentages. The conversion results are as follows (Cronbach 1990):

- $0 \%-64 \%=1$, very less precise / less obvious / less appropriate, revised.
- $65 \%-79 \%=2$, less precise / less obvious / less appropriate, revised.

- $80 \%-89 \%=3$, exact / clear / appropriate, unrevised.

- $90 \%-100 \%=4$, very precise / very clear / very appropriate, not revised.

Based on expert judgment and field test of the development components, the development component that obtains ratings 1 and 2 has a revised criterion. Furthermore, to measure the level of effectiveness of the model of career counseling for self-knowledge and occupation knowledge for special senior high school cerebral palsy students is analyzed in the descriptive statistical used to process the results of major field trials or minor scale. The basis of data processing of test results is quantitative collected from the test of selfknowledge and occupation knowledge

\section{RESULTS AND DISCUSSION}

\subsection{Result}

3.1.1 Results of Career Guidance Service Product for SelfKnowledge and Occupation Knowledge of The Cerebral Palsy Students in Special Senior High School

The results of this study begin with a literature analysis combined with results of field-studies related to the condition of cerebral palsy students in special senior high school to give effectiveness of career guidance service product for selfknowledge and occupation-knowledge is developed using a model CIP (Sampson \& Reardon 1991, Peterson et al. 1996, Sampson et al. 1999, 2000, Sharf 2002, Osborn et al. in Zunker 2002).

\subsubsection{Small Scale Test Results / Main Field Test Results}

In the implementation of small-scale test or main field test aims to test the level of effectiveness, especially on the usefulness or the use of career guidance services for selfknowledge and occupation knowledge of cerebral palsy students in special senior high school. Step to verify the test of self-knowledge and occupation-knowledge is implemented through parametric statistical tests. The following stages in the implementation of small-scale trials or main field test is as follows. 
TABLE I. SMALL SCALE TEST RESULT PART I

\begin{tabular}{|c|c|c|c|c|c|c|c|}
\hline \multirow{3}{*}{ No } & \multirow{3}{*}{$\begin{array}{l}\text { Student's } \\
\text { name }\end{array}$} & \multirow{2}{*}{\multicolumn{2}{|c|}{$\begin{array}{c}\text { Interest } \\
\text { Knowledge }\end{array}$}} & \multirow{2}{*}{\multicolumn{2}{|c|}{$\begin{array}{c}\text { Ability } \\
\text { Knowledge }\end{array}$}} & \multirow{2}{*}{\multicolumn{2}{|c|}{$\begin{array}{l}\text { Personality } \\
\text { Knowledge }\end{array}$}} \\
\hline & & & & & & & \\
\hline & & $\begin{array}{l}\text { Pre- } \\
\text { test }\end{array}$ & $\begin{array}{c}\text { Post- } \\
\text { test }\end{array}$ & $\begin{array}{l}\text { Pre- } \\
\text { test }\end{array}$ & $\begin{array}{l}\text { Post- } \\
\text { test }\end{array}$ & $\begin{array}{l}\text { Pre- } \\
\text { test }\end{array}$ & $\begin{array}{l}\text { Post- } \\
\text { test }\end{array}$ \\
\hline 1 & Nabila & 18 & 19 & 25 & 28 & 18 & 16 \\
\hline 2 & Deden & 17 & 17 & 24 & 23 & 18 & 14 \\
\hline 3 & Mala & 18 & 20 & 29 & 32 & 11 & 9 \\
\hline 4 & Nopi & 19 & 15 & 27 & 23 & 15 & 14 \\
\hline
\end{tabular}

TABLE II. SMALL SCALE TEST RESULT PART 2

\begin{tabular}{|c|c|c|c|c|c|c|c|}
\hline \multirow[t]{3}{*}{ No } & \multirow[t]{3}{*}{$\begin{array}{l}\text { Student's } \\
\text { name }\end{array}$} & \multicolumn{2}{|c|}{$\begin{array}{l}\text { Values and } \\
\text { attitudes }\end{array}$} & \multicolumn{2}{|c|}{$\begin{array}{c}\text { Ideals or } \\
\text { individual } \\
\text { thinking } \\
\text { pattern } \\
\text { about work }\end{array}$} & \multicolumn{2}{|c|}{$\begin{array}{c}\text { Self- } \\
\text { knowledge } \\
\text { with the } \\
\text { field of } \\
\text { work they } \\
\text { want }\end{array}$} \\
\hline & & Kno & ledge & Kno & ledge & Kno & ledge \\
\hline & & $\begin{array}{l}\text { Pre- } \\
\text { test }\end{array}$ & $\begin{array}{c}\text { Post- } \\
\text { test }\end{array}$ & $\begin{array}{r}\text { Pre- } \\
\text { test }\end{array}$ & $\begin{array}{l}\text { Post- } \\
\text { test }\end{array}$ & $\begin{array}{r}\text { Pre- } \\
\text { test }\end{array}$ & $\begin{array}{r}\text { Post- } \\
\text { test }\end{array}$ \\
\hline 1 & Nabila & 22 & 25 & 12 & 12 & 20 & 20 \\
\hline 2 & Deden & 25 & 24 & 11 & 15 & 16 & 14 \\
\hline 3 & Mala & 21 & 20 & 12 & 11 & 20 & 19 \\
\hline 4 & Nopi & 20 & 18 & 10 & 9 & 19 & 15 \\
\hline
\end{tabular}

After the results of data collection is presented in form of table. This tabulation as a way to classify the adjusted data through the rank or group of data collected both pre-test and post-test. Based on the result of the different test above, the interest knowledge shows the value of $t=0.861$ which falls on the significance of $0.000(<0,05)$. This means that there is a difference in understanding the interest of the cerebral palsy students in special senior high school between pre-test results and the post-test after career guidance. While the results of different test to understand ability, demonstrate the value of $t$ $=0.037$, which falls on a significance of $0.000(<0.05)$. This means that there is no difference of understanding ability of cerebral palsy students in special senior high school between the pre-test and post-test after career guidance. In the result of different test to understand the personality of cerebral palsy students in special senior high school shows the value of $\mathrm{t}=$ 0.037 , which falls on a significance of $0.000(<0.05)$. This means that there is no difference of understanding the personality of cerebral palsy students in special senior high school, between the pre-test and post-test after career guidance. Then the results of different test to understand the values and attitudes show the value of $\mathrm{t}=0.836$ which falls on the significance of $0.000(<0.05)$. This means that there are differences in understanding values and attitudes of cerebral palsy students in special senior high school, between the pretest and post-test after career guidance.

Further statistical analysis results in the understanding of work shows that the results of knowing ideals or individual thinking pattern about work, show the value of $\mathrm{t}=$ 0.703 Which falls on the significance of $0,000(<0.05)$. This means that there are differences in knowledge in understand the ideals or individual thinking pattern about work ideals of cerebral palsy students in special senior high school, between the pre-test and post-test after career guidance. In the results of understanding the self-knowledge with the field of work they want, showed the value of $\mathrm{t}=0.703$ falls on the significance of $0,000 \quad(<0.05)$. This means that there are differences in understanding the self -knowledge with the field of work they want. Based on the qualitative data obtained from cognitive reorganization of the components of selfknowledge and work knowledge. In the self-knowledge component data was obtained through the way of tracking the development of interest in the interests, ability, personality, values and attitudes of cerebral palsy students in special senior high school. Then for the component of the work knowledge data was obtained through understanding the ideals, individual thinking pattern about work and the understanding of selfknowledge about the flied of work that they want.

Then the basic reflection / expression of experience on the activities / work in accordance with the cerebral palsy students ability to self-knowledge and occupation knowledge on four research subjects based on the research findings suggest that the activity in the home, school and community through the data collection, indicate that a) one cerebral palsy students in daily activities like learning to cook, b) two cerebral palsy students in activities like to do activity with their relatives and also to learn the computer, c) one cerebral palsy students is facilitated to learn and work to help their parents.

\subsection{Discussion}

Career guidance book on career guidance service for selfknowledge and occupation knowledge is classified from 1) self-knowledge including: (a) interest, (b) ability, (c) personality, (d) values and attitudes; 2) occupation knowledge consisting of: (a) the ideals /individual thinking pattern about work, (b) self-knowledge about the flied of work that they want. Furthermore, the effectiveness of career guidance services for self-knowledge and occupation knowledge in its implementation using group counseling techniques through cerebral palsy students focus groups discussions (FGD).

In fact, that cerebral palsy students in senior high school have a characteristic of inability to receive auditory stimuli, language poverty, emotional incompetence and limitation of intelligence associated with social attitudes on them, which 
inhibited the development of his personality. Therefore cerebral palsy students have problems in understanding selfknowledge and occupation knowledge, so that career guidance from counselors and teachers in special senior high school is necessary, this statement was reinforced by the opinions of Herr \& Cramer (1984), which suggests the purpose of career counseling in secondary schools is to help students to learn a lot of important things.

Prominent behavior on cerebral palsy students are generally irritable, does not give long attention to something, and feel isolated from family and friends. Empirical evidence of the condition of cerebral palsy students in special senior high school, especially when guidance activities show that they are able perform their interest, although minimal to the field of work. The service for cerebral palsy students in career guidance for self-knowledge and occupation knowledge aims to actualize the capabilities that can still be developed. Therefore, the task of counselor and teacher in special senior high school is to provide maximum guidance for cerebral palsy students. This is confirmed by Pearsons in Zunker 2002 who states that the important benefits of career guidance from conceptual framework to help individuals choosing career.

\section{CONCLUSION}

Based on the effectiveness test of career guidance service product for self knowledge and occupation knowledge for cerebral palsy students in senior high school have been effective to optimize the change of knowledge about understanding of interest, ability, values and attitude, ideals/individual thinking pattern about work, and self knowledge on about the field of work that they want. While the results of the measurements test on cerebral palsy students' understanding of knowledge, obtained by statistical analysis of test results is less significant for ability, which show $t=0.037$ less than $(<0.05)$. The lack of effectiveness was caused by cerebral palsy students condition who experience psychological problems due to difficulty in expressing thoughts, desires and wills. In addition potential level of intelligence or intelligence, $60 \%$ of cerebral palsy students experiencing mental retardation, $70 \%$ had speech disorders, and between $40 \%$ - 50 had hearing impairment.

\section{REFERENCES}

[1] Gall, et al., Educational Research: An Introduction. United States, Pearson Education, Inc, 2007

[2] R. L. Gibson, \& M. H. Mitchell, Introduction to Counseling and Guidance. New Jersey: Pearson Prentice Hall, Pearson Education, Inc., 2008

[3] Herr \& Cramer, Career Guidance and Counseling Through Life Span:Systematic Approach. Boston: Little, Brown Company, 1984

[4] Sampson et al., "A Cognitive Information Processing Approach to Employment Problem Solving and Decision Making", in The Career Development Quarterly, Vol. 48, pp 3-18, 1999

[5] Sampson et al., "Using Readiness Assessment to Improve Career Service: A Cognitive Information Processing Approach", in The Career Development Quarterly, pp 49-174, 2000

[6] R.S. Sharf, Applying Career Development Theory to Counseling Third. Edition. Australia: Brooks / Cole, 2002

[7] D. E. Super, "A life-span, life space approach to career development", in Journal of Vocational Behavior, Vol. 13, pp 282-298, 1980

[8] V. G. Zunker, Career Counseling: Applied Concepts of Life Planning. Sixth Edition. United Kingdom: Brooks / Cole, 2002

[9] V. G. Zunker, \& D. S. Osborn, Using Assessment Results for Career Development, Sixth Edition. United Kingdom: Brooks / Cole, 2002

[10] W. Osier, The Cerebral Palsies of Children. A Clinical Study for the Infirmary for Nervous Diseases. Philadelphia: Blakiston, 1899

[11] Little Club, "Memorandum on terminology and classification of'cerebral palsy"' (MacKeith R., et al., editors), in Cereb Palsy Bull Vol. 1, pp 2735, 1959

[12] Bax MCO, "Terminology and classification of cerebral palsy", in Dev Med Child Neurol Vol. 6, pp 295-307, 1964

[13] P James, et al., Career Counseling and Services: Cognitive Information Processing Approach. Florida: Florida State University, 2013

[14] W B Gordon, Cognitive Interviewing: A Toll for Improving Questionnaire Design. United Kingdom: Sage Publication, 2004

[15] R Januce and C J Martyn, "Essential elements of questionaire design and development", in Journal of Clinical Nursing, Vol 16 Issue 2, 2007 